\title{
The Lifecycle of a Voluntary Policy Innovation: The Case of Local Agenda 21
}

\author{
Marta Pinto ${ }^{1}$, Marta Macedo ${ }^{1}$, Pedro Macedo ${ }^{1}$, Conceição Almeida ${ }^{1} \&$ Margarida Silva ${ }^{1}$ \\ ${ }^{1}$ Universidade Católica Portuguesa, Porto, Portugal \\ Correspondence: Margarida Silva, Centro de Biotecnologia e Química Fina—Laboratório Associado, Escola \\ Superior de Biotecnologia, Universidade Católica Portuguesa, Porto, Portugal. E-mail: msilva@esb.ucp.pt
}

Received: January 29, 2015

Accepted: February 22, 2015 Online Published: May 31, 2015

doi:10.5539/jms.v5n2p69

URL: http://dx.doi.org/10.5539/jms.v5n2p69

\begin{abstract}
Local Agenda 21 (LA21) emerged 23 years ago as a voluntary policy innovation for local governments aiming at sustainability and has now completed its lifecycle. We aim at a second look at LA21 from the standpoint of the institutional and innovation diffusion theories and with Portugal as case study. Results show a three moment lifecycle for LA21, each with distinct diffusion patterns. The Dawn, stymied by lack of regional and national leadership, was likely fuelled by a learning mechanism. It lasted 10 years and involved a mere $1 \%$ of the potential adopters. The Zenith took place when other countries had already come full circle. During this phase $27 \%$ of the local governments became active and both coercion and competition stand out as relevant engines. Twilight, most probably powered through coercion, competition and imitation mechanisms, took LA21 to a steady state with an additional $19 \%$ of local governments enrolling. Since then LA21 has shown departures in several different directions, including oblivion. We speculate, based on preliminary data that, although most LA21 are no longer active, a durable setting was created that promotes further innovation and public participation.
\end{abstract}

Keywords: indirect observation, innovation diffusion, local Agenda 21, local sustainability, policy innovation, Post LA21

\section{Introduction}

Local Agenda 21 (LA21) is considered to be a voluntary policy innovation for local governments (LG) with a primary goal of activating the local level to create sustainable communities (Joas \& Gronholm, 2004; Seyfang \& Smith, 2007).

Europe is unquestionably the world region where LA21 best anchored (Evans \& Theobald, 2003; Smardon, 2008), even if dissemination is far from consistent among European nations (Barrutia \& Echebarria, 2011; Joas \& Gronholm, 2004). Literature often mentions that LA21 is virtually non-existent in Portugal (Aguado, Echebarria, \& Barrutia, 2007; Barrutia \& Echebarria, 2011; Carter, Silva, \& Magalhães, 2000; Echebarria, Barrutia, \& Aguado, 2009)) where a long lack of interest foresaw no future for such a process and led to a 'latecomer' label as regards LA21 adoption (Joas \& Gronholm, 2004).

However, contrary to expectations and in stark contrast to most European LA21 'pioneer' and even 'follower' nations where LA21 was nearing a stationary phase (Gomila, 2000a; Joas \& Gronholm, 2004; Lafferty, 2001), a late and unexpected blossoming occurred in Portugal. How this came to happen and what lessons it holds for future local policy innovation diffusion waves elsewhere has not been subject to analysis.

Although focused on a single country, this is the right time - two decades after Agenda 21 was first written - to reflect with the benefit of hindsight on the institutionalization and full lifecycle of this innovation, with a particular focus on determinants and patterns of diffusion (Bingham, 1977) and its role as a source of further novelties (Geissel, 2009). To analyze change we draw upon the institutional theory and the diffusion of innovation theory as main theoretical frameworks.

\subsection{Local Agenda 21 as a Local Policy Innovation}

In 1992 over 178 governments met for the United Nations Conference on Environment and Development, (UNCED) widely known as Rio Summit and adopted Agenda 21 (A21), a transnational program including both sustainable development and governance objectives (Joas \& Gronholm, 2004). It includes a clear call for local authorities to adopt a Local Agenda 21, a policy innovation with the ultimate goal of improving local sustainable 
development prospects (Joas \& Gronholm, 2004) through citizen involvement (Elgert \& Krueger, 2012). The classic - but not standardized - sequence of the implementation of LA21 follows:

- Step 1: Political commitment to LA21 (affecting human and financial resources, engaging stakeholders);

- Step 2: Baseline review (elaboration of the sustainability report);

- Step 3: Local action plan (definition of sustainability targets and actions to accomplish them);

- Step 4: Implementation (taking forward the planned actions);

- Step 5: Evaluation and reporting (regular assessment of the results) (Garzillo \& Kuhn, 2007).

Policy innovations occur whenever a government — be it national or local—adopts a new policy (Shipan \& Volden, 2008). These innovations ultimately spread from one government to the next over timein a process known as diffusion (Kern, Koll, \& Schophaus, 2007; Rogers, 2002; Shipan \& Volden, 2008; Walker, 2006).

\subsection{Diffusion of Innovation Theory}

Rogers $(1983,2004)$ defines diffusion as the process by which an innovation (an idea perceived as new) is communicated through certain channels among the members of a population of potential adopters over time and asserts that the adoption of an innovation follows a normal, bell-shaped curve when plotted over time on a frequency basis and a S-shaped curve when cumulative number of adopters is considered. The S-shaped distribution rises slowly at first and then accelerates to a maximum until half of the individuals in the system have adopted. It then increases at a gradually slower rate as the few remaining individuals finally adopt. Each fraction of this curve represents a different adopter category based on time of adoption, which can be classified as follows (Rogers, 1983, 2002):

- Innovators (first $2.5 \%$ of adopters);

- $\quad$ Early adopters (13.5\%);

- $\quad$ Early majority (34\%);

- $\quad$ Late majority (34\%);

- $\quad$ Laggards (16\%).

The relative speed with which an innovation is adopted depends of the perceived attributes of the innovation as well as the way information about the innovation is communicated, the type of innovation decision (collective or authoritative), the characteristics of the social system (degree of interconnectedness and values) and the role of change agents (Rogers, 1983).

A variety of diffusion mechanisms for innovation diffusion have been identified. However, according to Shipan \& Volden (2008) and Gilardi (2012), a general consensus has formed around these four core paths:

- coercion - where outside pressure compels the adoption of a policy;

- competition - where rivalry between organizations prompts one to try to stay ahead of the other;

- learning — where knowledge is acquired mainly through peer networking;

- $\quad$ imitation — where one organization's innovations are copied by another seeking to look better.

Innovation carries many advantages, and likely drawbacks as well. For the purpose of the current narrative innovation matters since it provides a strategy of legitimation for organizations that sense the evolution in overarching institutions against which their own performance is measured (Damanpour \& Schneider, 2006; DiMaggio \& Powell, 1983).

\subsection{Institutional Theory}

According to institutional theory (Scott, 1995), institutions (government, family, religion, etc.) are resilient normative systems that organize social, political and economic life and stand on three pillars: regulatory, cognitive, and normative. Change in any of these pillars exerts pressure on related organizations. It has been argued that the narrative of sustainable development was the engine behind one such institutional change.

Ever since the Brundtland Report was published in 1987 the concept of sustainable development has entrenched itself firmly as a research object, a political concept and a set of skills, tools and practices. It has in fact become institutionalized - new values, perceptions, social norms and routines have been generated — and organizations at all levels (central governments, local governments, corporations) adopted them in order to maximize legitimacy and maintain social backing (Jennings \& Zandbergen, 1995; Llamas-Sanchez, Garcia-Morales, \& Martin-Tapia, 2013; Sneddon \& Norgaard, 2006). 
Over the decades the values, norms and civic involvement around sustainability never ceased to grow (Llamas-Sanchez, Munoz-Fernandez, \& Maraver-Tarifa, 2011), to the point where local decision makers' discourses started to incorporate appropriate wording (Schmidt, Nave, \& Guerra, 2005).

\subsection{Local Agenda 21: Adoption and Diffusion Behavior}

With the A21 agreement local authorities were recognized as an arena through which sustainability should be pursued (Kusakabe, 2013; Selman, 2010), and within the first decade a significant effort was made to move LA21 into practice. In 1994 the bottom-up European Sustainable Cities and Towns Campaign, consisting mainly of LG, was launched and played a key role in producing the Aalborg Charter (guidelines for sustainable European cities). ICLEI (Local Governments for Sustainability) constituted another engine of LA diffusion worldwide, creating a vast knowledge base and investing in numerous dissemination initiatives (Elgert \& Krueger, 2012).

Five years after the Rio Summit, LA21 activities were underway in more than 1800 LG in 64 countries worldwide (ICLEI-International Council of Local Environmental Initiatives, 1997). At this time, over $80 \%$ of the reported actions were taking place in 20 countries and a staggering $90 \%$ of initiatives happened in high-income nations. In 2002, LA21 had diffused to 6400 LG in 113 countries worldwide, a more than three-fold increase in less than five years. Over $80 \%$ of these LG were located in Europe (Rok \& Kuhn, 2012) one of the world regions where LA21 best took root (Evans \& Theobald, 2003; Smardon, 2008). However, the response from European local authorities to LA21 in Europe is far from homogeneous (Barrutia \& Echebarria, 2011; Joas \& Gronholm, 2004). Also, exactly how LA21 is implemented varies to a significant degree between countries and different political and administrative systems (Joas \& Gronholm, 2004).

In some European countries the LA21 implementation started soon after Rio. These 'pioneer' nations include Sweden, the United Kingdom and the Netherlands (Gomila, 2000a; Lafferty, 2001), whose national governments or LG associations significantly pushed for the diffusion of LA21 processes (Gomila, 2000a; Joas \& Gronholm, 2004; Jorby, 2002; Lafferty, 2001). All local authorities in Sweden had initiated LA21 process by early 1996 (Jorby, 2002) and by 1997 roughly 73\% of UK local authorities were involved in a LA21 process (Selman, 2000). These countries were then followed by their Scandinavian counterparts, such as Denmark, Finland and Norway, who had showed very little activity prior to 1996 and are considered 'followers' (Gomila, 2000a; Lafferty, 2001). Those nations that lagged behind and did not show any relevant activity before the end of the 1990s encompass Germany, France, Ireland, Austria, (Lafferty, 2001), Italy (Gomila, 2000a; Joas \& Gronholm, 2004), Spain and Portugal (Joas \& Gronholm, 2004). These nations have been described as 'latecomers' (Gomila, 2000a; Joas \& Gronholm, 2004; Lafferty, 2001). How European countries came to show such variable dynamics has been studied by several authors (Aguado et al., 2007; Evans, Joas, Sundback, \& Theobald, 2006).

There is still a notable lack of research on the diffusion of LA21, that being the case with other policy innovations at the local level as well (Shipan \& Volden, 2008; Wolman \& Page, 2002). It has however, albeit to a limited extent, been studied in Germany (Kern et al., 2007) and in Spain (Llamas-Sanchez et al., 2013; Llamas-Sanchez et al., 2011).

Several authors have identified a number of variables that influence LA21 diffusion: national GDP and level of citizen trust within a country (Owen \& Videras, 2008); governance style (Evans et al., 2006; Gomila, 2000a; Kern et al., 2007; Lafferty, 2001; Llamas-Sanchez et al., 2011); social and environmental experience and culture (Eckerberg \& Forsberg, 1998; Gram-Hanssen, 2000; Joas \& Gronholm, 2004; Jorby, 2002; Lafferty, 2001; Owen \& Videras, 2008; Schmidt, Nave, \& Guerra, 2006); existence of policy networks (Echebarria et al., 2009; Joas \& Gronholm, 2001; Lafferty, 2001; Rowe, 2000); existence of agenda transfer agencies (Fidelis \& Pires, 2009; Kern et al., 2007) and development of co-creation in networks (Barrutia \& Echebarria, 2011).

For LG, additional specific aspects have been identified: political orientation (Eckerberg \& Dahlgren, 2007; Garcia-Sanchez \& Prado-Lorenzo, 2008; Lorenzo \& Sánchez, 2009; Sancassiani, 2005); presence of key individuals such as politicians and public servants that imprint values and motivation (Barrutia, Aguado, \& Echebarria, 2007; Barrutia \& Echebarria, 2011; Eckerberg \& Forsberg, 1998; Evans, Joas, Sundback, \& Theobald, 2005; Evans et al., 2006; Harvold, 2003; Joas, Evans, \& Theobald, 2007); political autonomy (Eckerberg, 2000 cited in Echebarria et al., 2009; Joas \& Gronholm, 2004; Jonas, While, \& Gibbs, 2004 cited in Kern et al., 2007; Lafferty, 2001); operative capability (Agger, 2010; Garcia-Sanchez \& Prado-Lorenzo, 2008; Joas \& Gronholm, 2004); organizational size (Barrutia \& Echebarria, 2011; Kern et al., 2007; Llamas-Sanchez et al., 2011; Sancassiani, 2005); wealth (Dolowitz \& Marsh, 1996; Joas \& Gronholm, 2004; Kern et al., 2007); support from higher levels of government (Barrutia \& Echebarria, 2011; Coenen, 2001; Garcia-Sanchez \& Prado-Lorenzo, 2008; Gram-Hanssen, 2000; Lafferty, 2001; Lindstrom \& Johnsson, 2003; Littlewood \& While, 1997) and particularly financial support (Jorby, 2002; Llamas-Sanchez et al., 2011). 


\subsection{A Second Look at Local Agenda 21 now that It's Run Its Course}

Activities generated by Chapter 28 are seen as an inspiring post-Rio success (Lafferty, 2001; Rok \& Kuhn, 2012; Sneddon \& Norgaard, 2006) - in spite of the difficulties in gauging it as a result of its long term aims and often intangible intended outcomes (Geissel, 2009; Gram-Hanssen, 2000; Harvold, 2003; Jorby, 2002; Selman, 1998, 2000, 2010). LA21 has been credited with, among others, changing local democracy arenas (Agger, 2010; Holm, Stauning, \& Søndergård, 2009 cited in Holm, 2010; Joas \& Gronholm, 2001; Kusakabe, 2013; Rok \& Kuhn, 2012) and environmental policy options through enhanced citizen access to participation and transparency (Joas \& Gronholm, 2001); improving social capital (Geissel, 2009; Khakee, 2002); transforming the local authority itself as the sustainability debate permeates all departments and stimulates attitudinal and behavioral change (Selman, 1998) and reconciling top-down with bottom-up approaches (Selman, 1998).

Two decades later, however, times have changed. Most notably, the results of Rio+20 expressed in the outcome document titled 'The Future We Want' (United Nations Conference on Sustainable Development, 2012) contain no clear reference to LA21. It has also been reported by several authors that 'LA21' as a label has been losing momentum, at least in the UK (Rowe, 2000; Selman, 2000), Sweden (Eckerberg \& Dalgren, 2007 cited in Echebarria et al., 2009; Keskitalo \& Liljenfeldt, 2012) and Germany (Geissel, 2009; Kern et al., 2007).

Research has correspondingly dwindled. ICLEI reported on the frequency of the term 'LA21' as it appeared in English language literature between 1987 and 2008 (Rok \& Kuhn, 2012) and concluded that, after the enormous rise in popularity in the 1990s, there was a sharp decrease in its usage in the wake of Rio+20.

That LA21 is not longer diffusing can be ascertained using ICLEI's data relative to adoption of LA21 in European countries in 1997 and 2002, as well as information about LA21 adoption in Germany for 2006 (Kern et al., 2007), and estimating Europe's data point for 2008 by adjusting for Germany's increase (considering that most other countries had no significant additions at this time (Gomila, 2000a; Joas \& Gronholm, 2004; Lafferty, 2001)). With these numbers a graph for both Europe and Germany can be charted that fits - tentatively - the S-shaped curve of cumulative innovation diffusion (Rogers, 1983) where the final stationary phase represents the saturation point (Figure 1).

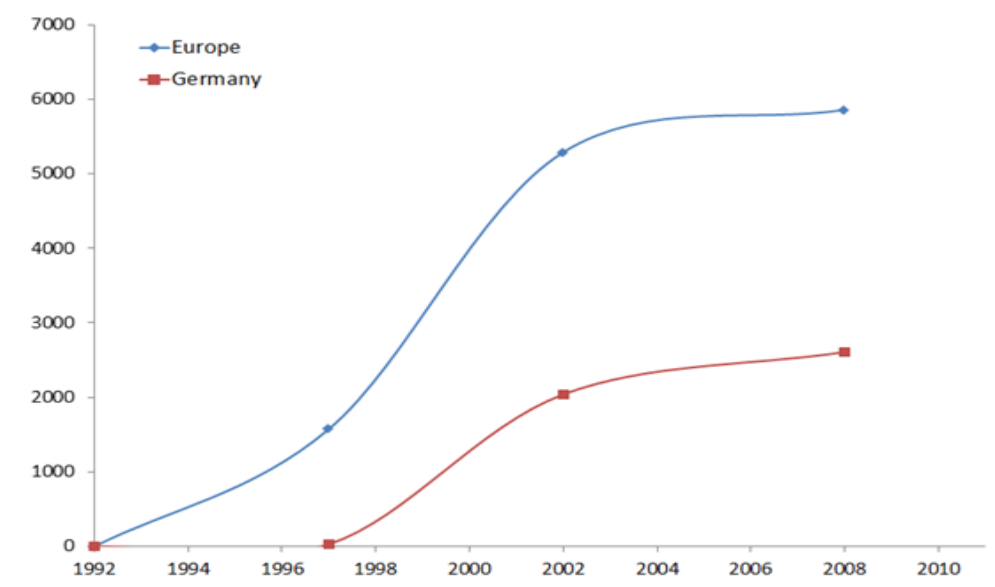

Figure 1. Curve of Local Agenda 21 diffusion in Europe and Germany based on data from ICLEI (1997), ICLEI (2002) and Kern, Koll, \& Schophaus (2007)

What happens after this point varies according to the innovations' own sustainability (Rogers, 1983). LA21 has been discontinued due to replacement in, for instance, the UK, where Sustainable Community Strategies took over (Fidelis \& Pires, 2009; Lucas, Ross, \& Fuller, 2001; Rowe, 2000; Selman, 2000) and Sweden, where Climate Change Adaptation Plans were adopted (Nilsson, Swartling, \& Eckerberg, 2012). Discontinuance may also occur through disenchantment, as was the case in Bergen, Norway (Harvold, 2003), among others.

Where innovations do take hold as such, two evolutionarily divergent paths can be taken. Routinization, or mainstreaming, happened in Ferrara and Fano, in Italy, and in Hanover, Germany (Evans et al., 2006), where LA21 became integrated into the local government's routine and somehow shed its separate self.

In the case of Botkyrka, Sweden, a redefinition, or restructuring, took place. Here the adoption led to the development of internal sustainability aims and work plans and a system of sustainability certification that aims at accrediting administrative units at the municipality (Keskitalo \& Liljenfeldt, 2012). It is called the 'Botkyrka 
model' as it joins together LA21 and standard management and ISO-like quality control systems.

Restructuring can alter the innovation itself, leading to new trends. Both Atkinson (2009) and O'Riordan (2001), among others, have argued that LA21 has given rise to the Transition Movement, a widening network of citizen initiatives seeking to address life after peak oil while avoiding the worst of climate change (Haxeltine \& Seyfang, 2009). It has also been suggested that LA21 has guided the way into the Covenant of Mayors and current public participation initiatives, such as participatory budgets (Kemp \& Rotmans, 2009; Seyfang \& Smith, 2007; Truffer \& Coenen, 2012).

\section{Methodology}

Previous research on LA21 made it clear that self-assessment processes should be avoided (Rok \& Kuhn, 2012). Self-reporting can introduce bias as a consequence of misperception of the LA21 concept (Lafferty, 2001) and social desirability, the tendency for respondents to behave in a culturally acceptable and appropriate manner (Podsakoff, MacKenzie, \& Lee, 2003; Podsakoff \& Organ, 1986; Richman, Kiesler, Weisband, \& Drasgow, 1999). Additionally, local government officials are overworked and such time-consuming tasks exceed their normal duties (Joas \& Gronholm, 2004).

One way to overcome such constraints is to use the indirect observation method, after the qualitative methods in social sciences (Bernard, 2000; Hewson, Yule, Laurent, \& Vogel, 2003). It consists of studying the physical traces a specific behavior leaves behind (Bernard, 2000). One of the new and interesting research settings to conduct indirect observation is the Internet (Bordia, 1996; Hewson et al., 2003), an efficient environment to retrieve suitable and relevant data (Hewson et al., 2003). The Internet is also a low-cost and efficient information sharing technology, unavoidable in dealing with people and organizations (Joseph \& Taplin, 2012), prompting public participation (J. Scott, 2006) and improving levels of citizen trust (Grimmelikhuijsen, 2012). Hence, here, the extent of LA21 adoption by Portuguese LG was assessed through the Internet, as the best mirror available for the citizen interaction entailed.

A first database of LA21 processes in Portugal was generated in 2006. For the purpose of this research it was fully revised twice (in 2011 and again in 2012). Data about each LA21 was initially sought by examining the LG' webpages looking for 'LA21' and 'local sustainability'. When no hits were found the Google search engine was used with 'LG name'+'Local Agenda 21'.

We analyzed and crosschecked all search outcomes. Results included local and national media outlets, sustainability baseline reports, action plan reports, official financial reports, local government webpages, consultant teams' webpages, seminar and conference proceedings and other academic publications. These sources provided information about LA21 processes, promoters, financing sources, year of adoption, step of implementation and population exposed. It should be highlighted that, for the purpose of this analysis, a LA21 process is any such self-designated initiative as well as any that, albeit not using the LA21 label, is comparable to it as long as its scope includes the three sustainable development pillars (social, environmental, economic). Excluded from this list were all environmental planning processes, even if they use a LA21 approach or label. Only processes led by LG or prompted and supported by them were taken into account. Some LA21, even though municipal in nature, were implemented only in specific areas (e.g. district). In such cases we considered only the number of inhabitants within the target area.

For Transition Initiatives, Covenant of Mayors, Eco-Management and Audit Scheme (EMAS) and ISO 14001 Environmental management systems membership was retrieved from the respective official webpages. The number of participatory budgets being implemented was accessed in www.op-portugal.org, a webpage that covers such experiences in the country.

\section{Results and discussion}

The degree of LA21 adoption by Portuguese LG (also known as municipalities) ranges from $0.3 \%$ in 1997, with only one of the 308 municipalities with LA21, to $47 \%$ in 2011(Figure 2). 


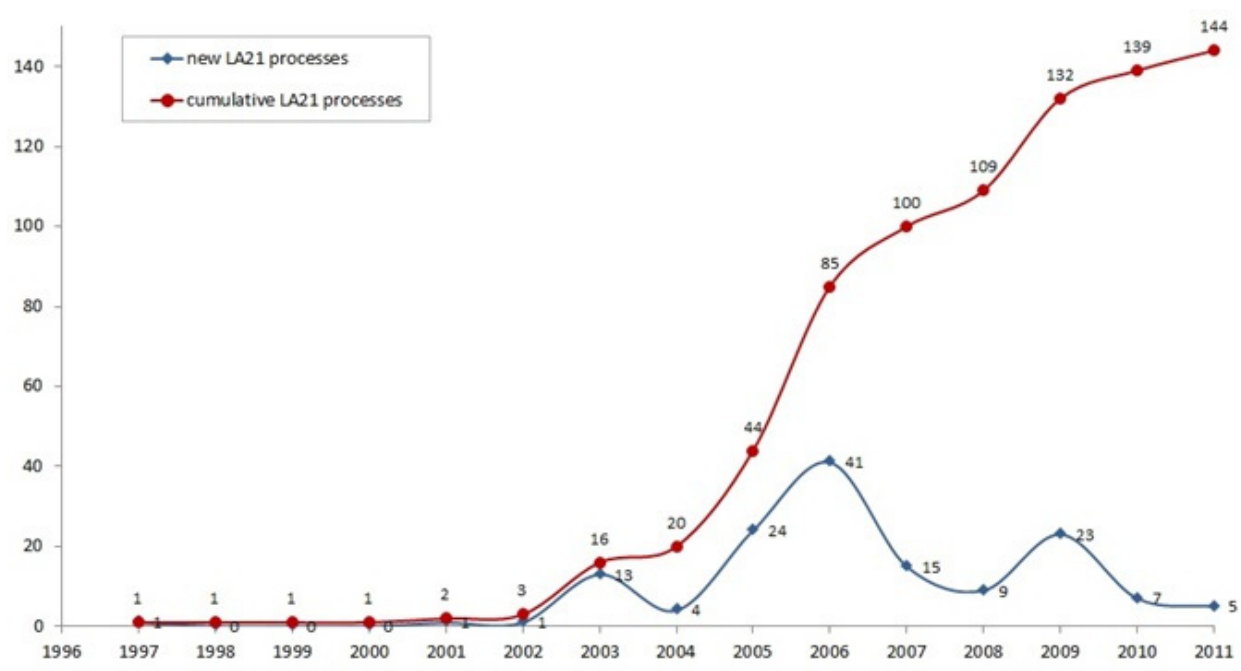

Figure 2. Early adoption of LA21 in Portugal and cumulative number of processes

Two other LA21 processes happened during this period but both took place outside municipalities and as such were not considered. In 2002, ten years after Rio, the adoption of LA21 in Portugal still had not reached 1\% of LG. That year was, however, a turning point: several LA21 processes were started and a highpoint was attained in 2006. A minor peak is perceived in 2009 and since then LA21 adoption slowed to a halt. The horizontal S-shaped curve over time described by Rogers (1983) is evident from the data, indicating the innovation saturation point was reached.

Chronologically the diffusion map of LA21 in Portuguese municipalities takes the shape presented in Figure 3. It becomes clear that several neighboring municipalities are adopting LA21 within the same year, revealing that diffusion is taking place, prompted by regional municipality networks.

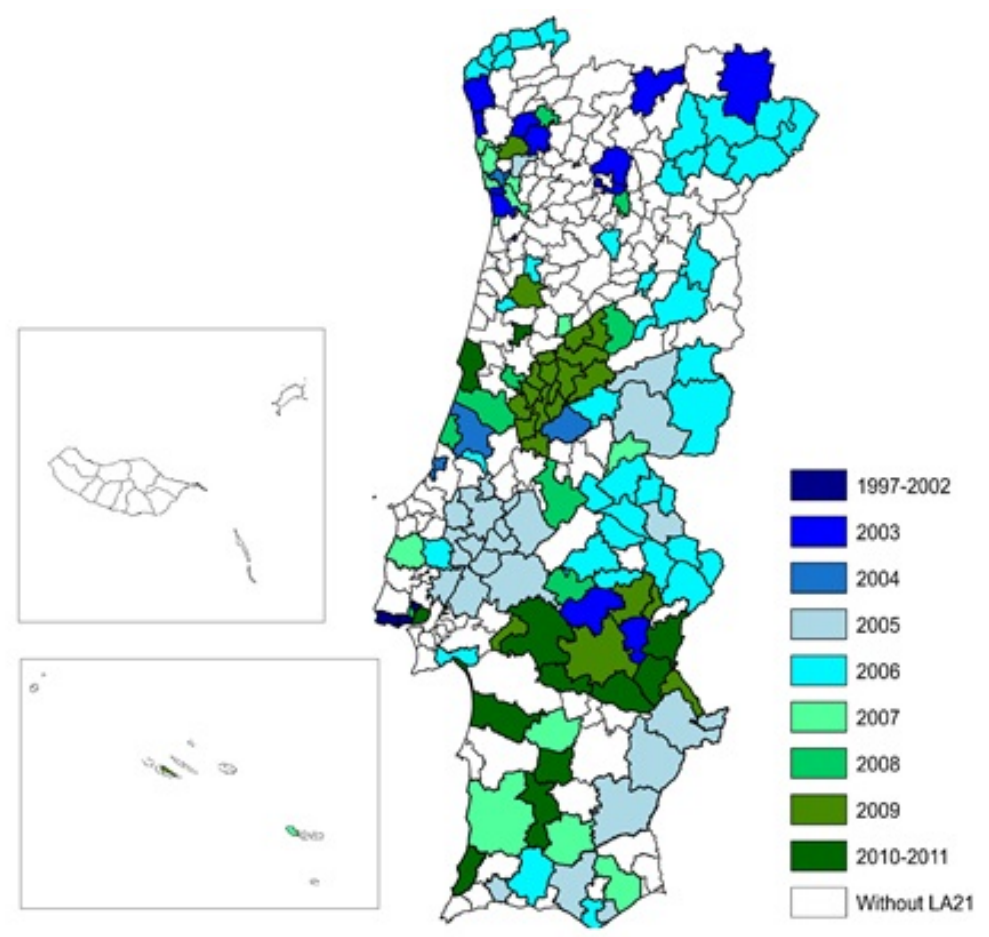

Figure 3. Diffusion of LA21 processes in Portugal (Continental Portugal, Madeira Archipelago and Azores Archipelago) 
Our data reveal an additional clear trend: average municipality population size adopting LA21 decreases with time (Figure 4). This is consistent with diffusion pattern research on LA21 in other European countries such as Germany and Italy, which reports that pioneers tend to be middle-sized or large cities (Kern et al., 2007; Sancassiani, 2005).

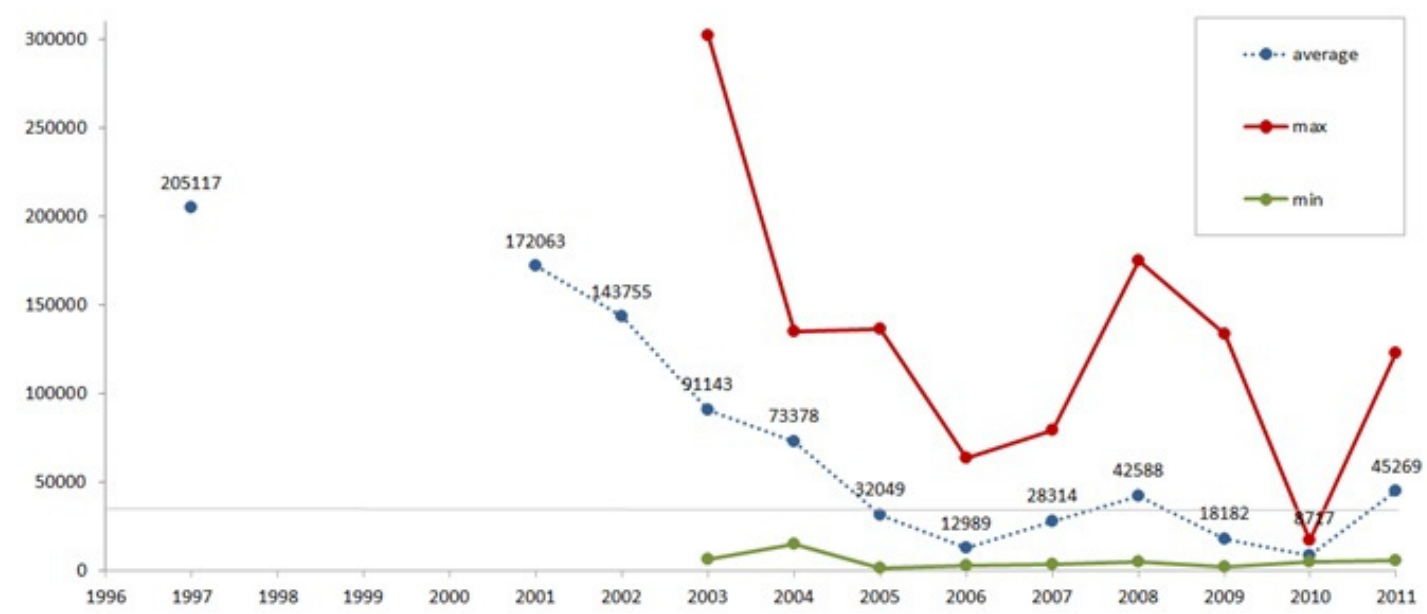

Figure 4. Average number of inhabitants living in municipalities that adopted LA21 processes per year. The number of residents living in municipalities with the highest population (max) and the lowest population effective (min) that adopted LA21 is also represented. The horizontal line in the plot area is the average number of inhabitants per municipality in Portugal (34 272).

The Portuguese late adoption trend parallels other southern European nations such as Italy, Greece and Spain, which also show a significant number of processes only after 2000 (ARE-Federal Office for Spatial Development, 2005; Gomila, 2000b; Sancassiani, 2005).

Figure 2 calls for a segmentation of the LA21 lifecycle in Portugal into three moments:

Dawn (1992-2002)

Zenith (2003-2006)

Twilight (2007-2011)

The main features of LA21 of each of these sections are described below.

\subsection{The Dawn (1992-2002)}

Literature supports the idea that recent democracies—-such as Portugal's — display lower levels of implementation of participatory processes towards sustainability (Schmidt et al., 2006). This translates into politician resistance to regular citizen interaction (Schmidt et al., 2006), with citizens unaware of public participation's true potential (Guerra \& Schmidt, 2009). The Portuguese also display low levels of social and political trust (Newton, 2001). This could have hindered LA21 adoption, as Owen and Videras (2008) suggest. Voluntary cooperation may be less likely to occur and policy innovations, such as LA21, which require coordination among multiple stakeholders, do not thrive.

Additionally, Portugal lacks an environmental culture (Schmidt et al., 2006; Silva \& Gonçalves, 2005). The first National Environmental Plan was published only in 1995. A parallel set of circumstances have been used to interpret Spain's poor LA21 early adoption record (Gomila, 2000a). Contrary to other European countries (e.g. Sweden), after Rio the Portuguese central government did not enforce, recommend or facilitate LA21 adoption (Aguado et al., 2007; Barrutia \& Echebarria, 2011; Carter et al., 2000; Echebarria et al., 2009; Fidelis \& Pires, 2009; Guerra \& Schmidt, 2009; Schmidt et al., 2005). Likewise, the National Association of Portuguese Municipalities did not step up to the role of LA21 transfer agency (Fidelis \& Pires, 2009), as opposed to what happened, for example, in England, with the Local Government Management Board (Gomila, 2000a).

Despite the limitations, three LA21 did start before 2003. The municipalities that individually overcame the 'risk perception' associated with LA21 (Barrutia \& Echebarria, 2011) were Cascais (1997), Oeiras (2001) and Odivelas (2002), all of them located within the capital city region, showcasing strong international ties and over 100.000 inhabitants. We suggest learning was the most relevant diffusion mechanism for these innovators, the reason being 
that both Cascais and Oeiras have long-term LA21 processes which are still active at the moment of this writing. When learning is the main mechanism behind adoption, longer-term effects and better results can be expected (Joas \& Gronholm, 2001; Shipan \& Volden, 2008).

The weak adoption of LA21 during this period certainly hampered its rate of diffusion, since it is accepted that a wide early adoption of policy innovations and network size are two crucial factors (Barrutia \& Echebarria, 2011). In Portugal critical mass was not reached during the Dawn period.

Networks and organizations such as the European Sustainable Cities and Towns Campaign, that create direct links between the local and the international levels, have been reported to be of particular importance in countries with no national support for local sustainability processes (Rok \& Kuhn, 2012), because they allow LG to find an alternative framework for cooperation and exchange (Rok \& Kuhn, 2012; Smardon, 2008), inspire action (Ramiery \& Fiorentini, 1998 cited in Gomila, 2000a) and, therefore, affect the degree of LA21 dissemination (Echebarria et al., 2009; Joas \& Gronholm, 2001). In Portugal, however, none of the 3 LA21 adopting municipalities subscribed the Aalborg pledges during this period.

At the end, in 2002, only 5\% of the Portuguese population was under a LA21 process. To adopt innovation, organizations should exchange information with the surrounding environment in order to improve knowledge, prepare members and facilitate assimilation into routines (Damanpour \& Schneider, 2006) but, if organizational leaders are not themselves ready, they cannot prompt for adoption. The lack of awareness of LA21 by local politicians has been specifically noted as a serious obstacle to adoption in Portugal (Carter et al., 2000), while Schmidt, Nave and Guerra (2005) observed that a mere $10 \%$ of local decision makers fully understood the concept of a LA21.

This, together with a lack of financial resources (Schmidt et al., 2005, 2006) and the fact that Portuguese local governance style is still quite old-fashioned (39\% of mayors declare that decision making should be reserved for elected politicians and $31 \%$ believe that citizens are not ready to play a more active role in local governance (Schmidt et al., 2006)), dampened most activity and can successfully explain the low interest in LA21 adoption during the Dawn period.

\subsection{The Zenith (2003-2006)}

Beginning 2003 Portuguese LA21 started bourgeoning: the annual average growth rate of LA21 adoption is $168 \%$ for the 2002-2006 period. At the end 85 LA21 processes were being implemented, involving $28 \%$ of municipalities and $31 \%$ of the population.

These figures suggest LG started seeing increased value and the availability of financial resources must have played a major role. Resources from European Union (EU) funded programs, such as the European Regional Development Fund (ERDF) and the European Social Fund - regionally administered - helped set up some LA21 initiatives. Our data reveal that $48 \%$ of all LA21 started in 2003-2006 were co-financed by EU programs, the ERDF being the funding source for $74 \%$ of those that did receive outside money.

The availability of financial resources is definitely of significance in European countries (Coenen, 2001; Echebarria et al., 2009; Eckerberg \& Dahlgren, 2007; Jorby, 2002; Sancassiani, 2005) and subsidy programs have proven beneficial in accelerating LA21 diffusion patterns (Echebarria et al., 2009; Kern et al., 2007; Llamas-Sanchez et al., 2011). In Portugal, however, and within the time frame considered, it does not explain the $52 \%$ of LA2 1 that were financed through regular municipal budgets.

The role of 'agenda transfer' institutions at the regional level (Kern et al., 2007) was finally taken up by regional municipality networks, which launched $63 \%$ of all LA21 processes during this time. Their main task was the application for and management of EU grants (Guerra \& Schmidt, 2009) but they also provided frameworks, information, technical support and a network enabling environment.

To avoid being left behind, LG may have felt they had no choice but to join the LA21 bandwagon - a sure sign of competition (Barrutia \& Echebarria, 2013). Consistently, Fidélis and Pires (2009) assert the 'agenda transfer' effect is the main engine behind LA21 during this period.

Universities and private companies also had a role in LA21 diffusion by providing expertise and training, together with field work. Contracts usually ran for 24 months and encompassed the first three phases of LA21. Of all LA21 born within this period, $95 \%$ were associated with an external team.

A perceived coercive mechanism may have been also at play during this period: some Portuguese municipalities expected that a working LA21would improve their chances of grant proposal approval under the then forthcoming National Strategic Reference Framework (2007-2013) that framed EU funding for Portugal (Assembleia 
Municipal de Pinhel, 2007).

\subsection{The Twilight (2007-2011)}

The final period is characterized by a deceleration in LA2 1 adoption. The average growth rate of LA21 adoption is now $11 \%$ yearly and the steady state is attained before half of the potentially adopting municipalities get involved. During this Twilight 59 new LA21 were created and co-financing reached its apex (59\% of these new LA21 received external funds). For the first time EU funding is explicitly available for municipalities wishing to implement LA21. Half of all new LA21 are adopted within a regional framing and almost all $(83 \%)$ involve external teams. The peak observed in 2009 (with 23 new LA21) is ultimately a consequence this financing, since 21 of those benefited from it.

As regards diffusion mechanisms we suggest that coercion, competition and imitation mechanisms must all have been at play. The first two as a result of the EU funding opportunities and the role of the 'agenda transfer' agencies, as explained previously, the latter because 'latecomers' - usually small municipalities as observed from our data (63\% of all new LA21 encompass less than 20.000 inhabitants) - may be looking up to their bigger neighbors and trying to keep up (Shipan \& Volden, 2008). This was illustrated by an official at a council meeting: 'our municipality should not defer any longer the adoption [...] many municipalities have already done it by now' (Assembleia Municipal de Penacova, 2010).

By the end of the Twilight period the diffusion of LA21 seems to have run its course. That the end would come so fast may be a consequence of the government announcing structural changes targeting municipalities, such as mergers, mandate changes, budget cuts, reduced autonomy and forced internal reorganization. This major move was announced at the 2011 general election. Instability ensued and the local political center of gravity shifted. Decreased autonomy, for instance, is considered a factor that hinders LA21 adoption (Joas et al., 2007; Jorby, 2000, 2002). The economic crisis that hit Portugal at the time compounded the issue and could also help explain the loss of momentum in LA21 adoption.

\subsection{Beyond the Twilight}

What happened to all these LA21? Did they deliver real outcomes? Our research suggests only 32 of all 144 (22\%) municipal LA21 are currently active, i.e., have real up-to-date Internet existence. In Great Britain, on the other hand, even though over $90 \%$ of LG saw LA21 as worthy, only about one third had firmly and durably embraced it (Tuxworth, 1996 cited in Rowe, 2000).

The Internet shows that not all 82 LA21 launched during the Zenith period fare well after their 5 to 8 year existence. One would expect that after this length of time all would have already started 'implementation' (Step 4) and 'evaluation and revision' (Step 5). However, in 2011, only 2\% of those 82 processes reached Step 5 and only $11 \%$ got to Step 4. Data reveals low levels of action, with 52\% jammed at the 'plan of action' stage (Step 3).

Beyond Step 3 the inability to implement the plan takes its toll, partly as a consequence of the retreat of the external teams.One mayor states their LA21 'is not dead but moribund because the external team is no longer available' (Assembleia Municipal do Bombarral, 2010). Another mayor clarifies that 'LA21 is largely abandoned because there is lack of money although some activities are still being implemented' (Camara Municipal de Manteigas, 2012). It is widely known this shortage of funds was partially unleashed and extensively aggravated by the 2008 bank meltdown and the 2010 Euro Zone crisis whose consequences, at least in Portugal, still ripple through everyday life many years later. Being as it is a voluntary policy, LA21 must have come high on the list of much needed spending cuts.

Interestingly, the percentage of all Portuguese LA21 that manage to reach Step 4 and $5(10 \%)$ does not differ between LA21 promoted by regional municipality networks and those initiated by individual municipalities. The 'agenda transfer' effect of regional associations of municipalities is clearly prompting diffusion but not the long term sustainability of the innovation, contrary to what other authors have reported (Barrutia et al., 2007; Joas \& Gronholm, 2001).

Some LA21, on the other hand, are still clearly active, having undergone a re-invention process over time (Rogers, 1983, 2004) and developed deep roots in municipalities such as Cascais and Oeiras, for instance, who were two of the early adopters.

Could it be that the incentive to further LA21 was drained through some related political measure? One of the most important new international agreements during the period under consideration was the Convention on Access to Information, Public Participation in Decision-Making and Access to Justice in Environmental Matters, better known as the Aarhus Convention. It enshrines, among others, the government's duty to ensure transparency and public participation in environmental issues and, as such, does overlap somewhat with LA21. This instrument, 
however, was adopted in 1998 and entered into force in 2001, and it was after that time that most LA21 were started and implemented in Portugal, meaning a direct cause and effect relationship is not apparent.

LA21 as a policy innovation has been shown to enable an evolutionary environment for governance, policy making and the sustainability transition (Agger, 2010; Atkinson, 2009; Joas \& Gronholm, 2001; Kemp \& Rotmans, 2009; Kusakabe, 2013; Leach et al., 2012; O'Riordan, 2001; Rok \& Kuhn, 2012; Selman, 2000; Truffer \& Coenen, 2012). So, it is possible that at least some LA21 have simply metamorphosed into something new, or more fashionable, while respecting the main pillars and lessons learnt.

We looked into EMAS, the European Eco-Management and Audit Scheme, but only a single Portuguese LG was certified through this system (Ponta Delgada), meaning LA21 did not spark this kind of interest. The same can be said of ISO 14 001, where a mere two LG had some of their departments certified (Esposende and Maia). It's likely these much more structured administrative approaches crossed too far from the participatory and holistic nature of most LA21 initiatives.

But other paths may have been spurred. Our data reveal that, of all Portuguese municipalities previously enrolled in a LA21 process, $25 \%$ later entered the Covenant of Mayors whereas only $14 \%$ of the non-LA21 adopters subscribed. As for municipalities with a participatory budget, $15 \%$ came with a LA21 background while only $8 \%$ were non-LA21 adopters. Also, two of the three official Transition Towns had LA21 programs. These numbers cautiously point to LA21 as an enabling settingfor some models of further policy innovation and grassroots initiatives.

\section{Conclusions}

Out of tune with most other European countries, LA21 started diffusing in Portugal five years after it was first approved. What took place afterwards survived governmental neglect and lack of a common vision, reaching a respectable $47 \%$ diffusion level. When no central leadership materialized some LG stepped in which, alone or within regional networks - and somewhat prodded through financing and expertise availability - found the necessary commitment to drive the process. That such results could be attained without organized governmental intervention is a tribute to the LA21 concept's intrinsic worth and places differing views (among others Barrutia \& Echebarria, 2011; Coenen, 2001) into perspective. The importance of leadership cannot be underestimated, however, and our results show that existence of an active regional coalition does seem to increase the chances of any individual $\mathrm{LG}$ of that region engaging in the process.

Overall, diffusion mechanisms identified throughout the LA21 lifecycle seemed sufficient to explain the measured evolution. Each period was marked by a specific subset of those mechanisms, which helped imprint the resulting pattern.

Innovations come and go, and what lives on after newer tides have swept people's attention defines the true sustainability of each trend. Portugal did not reach a major integration and so the national LA21 sustainability level can be classified as weak, even though a facilitating effect for further innovation could be detected.

Maximizing sustainability ought to be high on any government's or agency's agenda when it comes to promoting political innovations such as LA21, and our case study signals some of the variables involved.

Funding is a case in point. In each successive innovation round, when external funds do become available, past performance could be evaluated as criterion for differential sharing.Overall sustainability, as measured by actual innovation integration, should shape such an analysis.

As for external teams, they would do well to refocus the mandate from mere executors to capacity builders. The ability to internalize appropriate skills within the target institution that remain long after the temporary teams have left could well become the litmus test of their true success.

Finally, diversity should be upheld in the overall innovation cycle. Some stakeholders will always feel more motivated than others when faced with each particular option, and it is the motivated ones that have the best chance of moving further and internalizing deeper. By adding carrots and sticks increased numbers may follow along, but the innovation's sustainability level may not improve. If leeway is allowed - within basic constraints - internal motivation may prove the best button to push where innovation diffusion is concerned.

As mentioned by Leach et al. (2012), innovation itself must go through innovation by opening itself to the contributions of local grassroots innovation actors. By providing a safe operating space to such stakeholders an alternative engine might be started that keeps each innovation's sustainability running at maximum speed. 


\section{References}

Agger, A. (2010). Involving citizens in sustainable development: evidence of new forms of participation in the Danish Agenda 21 schemes. Local Environment: The International Journal of Justice and Sustainability, 15(6), 541-552. http://dx.doi.org/10.1080/13549839.2010.487526

Aguado, I., Echebarria, C., \& Barrutia, J. (2007). Implantación de la Agenda 21 Local en Europa: divergencias en ritmos y enfoques. Geographicalia, 51, 107-131.

ARE-Federal Office for Spatial Development. (2005). National Promotion of Local Agenda 21 in Europe (pp. 33).

Assembleia Municipal de Penacova. (2010). Acta da primeira sessão ordinária anual da Assembleia Municipal de Penacova, realizada no dia 20-02-2010 [Minutes for the first regular Municipal Assembly meeting of February 20th, 2010]. Penacova.

Assembleia Municipal de Pinhel. (2007). Acta da sessão ordinária da Assembleia Municipal realizada no dia 20 de dezembro de 2007 [Minutes for the Municipal Assembly meeting of December 20th, 2007]. Pinhel.

Assembleia Municipal do Bombarral. (2010). Acta $n^{\circ}$ 10/2010 - Reunião de 08 de Outubro de 2010 [Minutes for the Municipal Assembly meeting of October 8th, 2010]. Bombarral.

Atkinson, A. (2009). Cities after oil (one more time). City: analysis of urban trends, culture, theory, policy, action, 13(4), 493-498. http://dx.doi.org/10.1080/13604810903298706

Barrutia, J., \& Echebarria, C. (2011). Explaining and measuring the embrace of Local Agenda 21s by local governments. Environment and Planning A, 43(451-469). http://dx.doi.org/10.1068/a43338

Barrutia, J., \& Echebarria, C. (2013). Networks: a social marketing tool. European Journal of Marketing, 47, 324-343. http://dx.doi.org/10.1108/03090561311285574

Barrutia, J., Aguado, I., \& Echebarria, C. (2007). Networking for Local Agenda 21 implementation: Learning from experiences with Udaltalde and Udalsarea in the Basque autonomous community. Geoforum, 38, 33-48. http://dx.doi.org/10.1016/j.geoforum.2006.05.004

Bernard, R. (2000). Social Research Methods: Qualitative and Quantitative Approaches. Thousand Oaks, CA: Sage Publications.

Bingham, R. (1977). The diffusion of innovation among local governments. Urban Affairs Review, 13(2), 223-232. http://dx.doi.org/10.1177/107808747701300205

Bordia, P. (1996). Studying verbal interaction on the Internet: The case of rumor transmission research. Behavior Research Methods, Instruments, \& Computers, 28(2), 149-151. http://dx.doi.org/10.3758/BF03204753

Camara Municipal de Manteigas. (2012). Câmara Municipal de Manteigas - Ata $n^{\circ}$ 13/2012 [Minutes for the Local Government meeting of July 11th, 2012]. Manteigas.

Carter, N., Silva, F., \& Magalhães, F. (2000). Local Agenda 21: progress in Portugal. European urban and regional studies, 7(2), 181-186. http://dx.doi.org/10.1177/096977640000700207

Coenen, F. (2001). The Netherlands - probing the essence of Local Agenda 21 as a value-added approach to sustainable development and local democracy. In W. Lafferty (Ed.), Sustainable Communities in Europe (pp. 153-179). London: Earthscan.

Damanpour, F., \& Schneider, M. (2006). Phases of the Adoption of Innovation in Organizations: Effects of Environment, Organization and Top Managers. British Journal of Management, 17, 215-236. http://dx.doi.org/10.1111/j.1467-8551.2006.00498.x

DiMaggio, P., \& Powell, W. (1983). The iron cage revisited: institutional isomorphism and collective rationality in organizational fields. American Sociological Review, 48, 147-160. http://dx.doi.org/10.2307/2095101

Dolowitz, D., \& Marsh, D. (1996). Who Learns What from Whom: a Review of the Policy Transfer Literature. Political Studies, 44, 343-357. http://dx.doi.org/10.1111/j.1467-9248.1996.tb00334.x

Echebarria, C., Barrutia, J., \& Aguado, I. (2009). The ISC framework: modelling drivers for the degree of Local Agenda 21 implantation in Western Europe. Environment and Planning A, 41, 980-995. http://dx.doi.org/10.1068/a40301

Eckerberg, K., \& Dahlgren, K. (2007). Project or Process? Fifteen years experience with Local Agenda 21 in Sweden. Ekonomiaz, 64(1), 130-149. 
Eckerberg, K., \& Forsberg, B. (1998). Implementing Agenda 21 in local government: the Swedish experience. Local Environment: The International Journal of Justice and Sustainability, 3(3), 333-347. http://dx.doi.org/10.1080/13549839808725569

Elgert, L., \& Krueger, R. (2012). Modernising sustainable development? Standardisation, evidence and experts in local indicators. Local Environment: The International Journal of Justice and Sustainability, 17(5), 561-571. http://dx.doi.org/10.1080/13549839.2012.681466

Evans, B., \& Theobald, K. (2003). LASALA: Evaluating Local Agenda 21 in Europe. Journal of Environmental Planning and Management, 46(5), 781-794. http://dx.doi.org/10.1080/0964056032000138481

Evans, B., Joas, M., Sundback, S., \& Theobald, K. (2005). Governing Sustainable Cities. London: Earthscan.

Evans, B., Joas, M., Sundback, S., \& Theobald, K. (2006). Governing Local Sustainability. Journal of Environmental Planning and Management, 49(6), 849-867. http://dx.doi.org/10.1080/09640560600946875

Fidélis, T., \& Pires, S. (2009). Surrender or resistance to the implementation of Local Agenda 21 in Portugal: the challenges of local governance for sustainable development. Journal of Environmental Planning and Management, 52(4), 497-518. http://dx.doi.org/10.1080/09640560902868363

Garcia-Sanchez, I., \& Prado-Lorenzo, J.-M. (2008). Determinant Factors in the Degree of Implementation of Local Agenda 21 in the European Union. Sustainable Development, 16, 17-34. http://dx.doi.org/10.1002/sd.334

Garzillo, C., \& Kuhn, S. (2007). The Aalborg Commitments Implementation Guide-A 5-Step Approach. Frankfurt: ICLEI (International Council of Local Environmental Initiatives).

Geissel, B. (2009). Participatory Governance: Hope or Danger for Democracy? A Case Study of Local Agenda 21. Local Government Studies, 35(4), 401-414. http://dx.doi.org/10.1080/03003930902999522

Gilardi, F. (2012). Transnational diffusion: Norms, ideas, and policies. In W. Carlsnaes, T. Risse, \& B. Simmons (Eds.), Handbook of International Relations (pp. 453-477). Thousand Oaks: Sage Publications.

Gomila, M. (2000a). La Agenda 21 Local en Europa: un análisis comparado. In N. Font \& J. Subirats (Eds.), Local y Sostenible: La Agenda 21 Local en España (pp. 29-64). Barcelona: Icaria.

Gomila, M. (2000b). Participación, gobierno local y Agenda 21 Local. In N. Font \& J. Subirats (Eds.), Local y Sostenible: La Agenda 21 Local en España (pp. 65-91). Barcelona: Icaria.

Gram-Hanssen, K. (2000). Local Agenda 21: Traditional Gemeinschaft or Late-Modern Subpolitics? Journal of Environmental Policy \& Planning, 2(3), 225-235.

Grimmelikhuijsen, S. (2012). Linking transparency, knowledge and citizen trust in government: an experiment. $\begin{array}{lllll}\text { International Review of } & \text { Administrative } & \text { Sciences, } & 78(1), & 50-73 .\end{array}$ http://dx.doi.org/10.1177/0020852311429667

Guerra, J., \& Schmidt, L. (2009). Da Carta aos Compromissos de Aalborg-Sustentabilidade Local em Portugal no Contexto Europeu. Paper presented at the Conferência Internacional "Experiências de Agendas 21 Local: os desafios do nosso tempo", Ponta Grossa, Brazil.

Harvold, K. (2003). Consensus or Conflict? Experiences with Local Agenda 21 Forums in Norway. Local Government Studies, 29(4), 117-135. http://dx.doi.org/10.1080/03003930308559392

Haxeltine, A., \& Seyfang, G. (2009). Transitions for the People: Theory and Practice of 'Transition'and 'Resilience'in the UK's Transition Movement (pp. 35): Tyndall Centre for Climate Change Research.

Hewson, C., Yule, P., Laurent, D., \& Vogel, C. (2003). Internet Research Methods: A Practical Guide for the Social and Behavioural Sciences. London: Sage.

Holm, J. (2010). Local Experimentation and Deliberation for Sustainable Development: Local Agenda 21 Governance. In K. Nielsen, B. Elling, M. Figueroa, \& E. Jelsøe (Eds.), A new Agenda for Sustainability (pp. 205-228). Burlington, VT: Ashgate Publishing.

ICLEI-International Council of Local Environmental Initiatives. (1997). Local Agenda 21 Survey: A Study of Responses by Local Authorities and Their National and International Associations to Agenda 21 prepared by ICLEI in co-operation with the United Nations Department for Policy Coordination and Sustainable Development.

ICLEI-International Council of Local Environmental Initiatives. (2002). Second Local Agenda 21 Survey: Department of Economic and Social Affairs. 
Jennings, P., \& Zandbergen, P. (1995). Ecologically Sustainable Organizations: An Institutional Approach. The Academy of Management Review, 20(4), 1015-1052.

Joas, M., \& Gronholm, B. (2001). Local Level Sustainability Policies in the Baltic Sea Area: Local Agenda 21 within the Union of the Baltic Cities Network. Ambio: A Journal of the Human Environment, 30(4), 315-319.

Joas, M., \& Gronholm, B. (2004). A comparative perspective on self-assessment of Local Agenda 21 in European Cities. Boreal Environment Research, 9, 499-507.

Joas, M., Evans, B., \& Theobald, K. (2007). Local Agenda 21 in Europe-the second phase of ecological modernisation in local government. Ekonomiaz, 64(1), 92-105.

Jorby, S. (2000). Local Agenda 21 in practice-A Swedish example. Sustainable Development, 8(4), 201-214. http://dx.doi.org/10.1002/1099-1719(200011)8:4\%3C201::AID-SD147\%3E3.0.CO;2-0

Jorby, S. (2002). Local Agenda 21 in four Swedish Municipalities: a tool towards sustainability. Journal of Environmental Planning and Management, 45(2), 219-244. http://dx.doi.org/10.1080/09640560220116314

Joseph, C., \& Taplin, R. (2012). International initiatives influence on local government sustainability web-disclosures. Social Responsibility Journal, 8, 589-602. http://dx.doi.org/10.1108/17471111211272561

Kemp, R., \& Rotmans, J. (2009). Transitioning policy: Co-production of a new strategic framework for energy innovation policy in the Netherlands. Policy Sciences, 42(4), 303-322. http://dx.doi.org/10.1007/s11077-009-9105-3

Kern, C., Koll, C., \& Schophaus, M. (2007). The diffusion of Local Agenda 21 in Germany: Comparing the German federal states. Environmental Politics, 16(4), 604-624. http://dx.doi.org/10.1080/09644010701419139

Keskitalo, C., \& Liljenfeldt, J. (2012). Working with sustainability: Experiences of sustainability processes in $\begin{array}{lllll}\text { Swedish } & \text { Nunicipalities. }\end{array}$ http://dx.doi.org/10.1111/j.1477-8947.2012.01442.x

Khakee, A. (2002). Assessing Institutional Capital Building in a Local Agenda 21 Process in Göteborg. Planning Theory \& Practice, 3(1), 53-68. http://dx.doi.org/10.1080/14649350220117807

Kusakabe, E. (2013). Advancing sustainable development at the local level: The case of machizukuri in Japanese cities. Progress in Planning, 80, 1-65. http://dx.doi.org/10.1016/j.progress.2012.06.001

Lafferty, W. (Ed.). (2001). Sustainable communities in Europe. London: Earthscan.

Leach, M., Rockström, J., Raskin, P., Scoones, I., Stirling, A., Smith, A., . . Olsson, P. (2012). Transforming innovation for sustainability. Ecology and Society, 17(2), 11. http://dx.doi.org/10.5751/ES-04933-170211

Lindstrom, M., \& Johnsson, P. (2003). Environmental Concern, Self-concept and Defence Style: a study of the Agenda 21 process in a Swedish municipality. Environmental Education Research, 9(1), 51-66. http://dx.doi.org/10.1080/13504620303470

Littlewood, S., \& While, A. (1997). A new Agenda for governance? Agenda 21 and the prospects for holistic local decision making. Local Government Studies, 23(4), 111-123. http://dx.doi.org/10.1080/03003939708433889

Llamas-Sanchez, R., Garcia-Morales, V., \& Martin-Tapia, I. (2013). Factors affecting institutional change: a study of the adoption of Local Agenda 21 in Spain. Journal of Organizational Change Management, 26, 1045-1070. http://dx.doi.org/10.1108/JOCM-03-2012-0037

Llamas-Sanchez, R., Munoz-Fernandez, A., \& Maraver-Tarifa, G. (2011). The local agenda 21 in Andalusia, Spain: A model for sustainable innovation. African Journal of Business Management, 5(32), 12653-12663.

Lorenzo, J., \& Sánchez, I. (2009). Efecto de las estructuras organizativa y política del gobierno municipal en la organización social de la Agenda 21 Local. Revista de Economía Mundial, 21, 195-226.

Lucas, K., Ross, A., \& Fuller, S. (2001). Local Agenda 21: When is it a model for joined up community based activity. In C. f. S. Development (Ed.), Working Papers. London: University of Westminster.

Newton, K. (2001). Trust, social capital, civil society, and democracy. International Political Science Review, 22(2), 201-214. http://dx.doi.org/10.1177/0192512101222004

Nilsson, A., Swartling, A., \& Eckerberg, K. (2012). Knowledge for local climate change adaptation in Sweden: 
challenges of multilevel governance. Local Environment: The International Journal of Justice and Sustainability, 17(6-7), 751-767. http://dx.doi.org/10.1080/13549839.2012.678316

O'Riordan, T. (2001). Globalism, localism, and identity: fresh perspectives on the transition to sustainability. London: Earthscan.

Owen, A., \& Videras, J. (2008). Trust, cooperation, and implementation of sustainability programs: The case of $\begin{array}{lllll}\text { Local Agenda 21. Ecological } & \text { Economics, }\end{array}$ http://dx.doi.org/10.1016/j.ecolecon.2008.03.006

Podsakoff, P., \& Organ, D. (1986). Self-reports in organizational research: Problems and prospects. Journal of Management, 12, 69-82. http://dx.doi.org/10.1177/014920638601200408

Podsakoff, P., MacKenzie, S., \& Lee, J. (2003). Common method biases in behavioral research: A critical review of the literature and recommended remedies. Journal of Applied Psychology, 88, 879-903. http://dx.doi.org/10.1037/0021-9010.88.5.879

Richman, W., Kiesler, S., Weisband, S., \& Drasgow, F. (1999). A meta-analytic study of social desirability distortion in computer administered questionnaires, traditional questionnaires, and interviews. Journal of Applied Psychology, 84, 754-775. http://dx.doi.org/10.1037/0021-9010.84.5.754

Rogers, E. (1983). Diffusion of innovations. New York.

Rogers, E. (2002). Diffusion of preventive innovations. Addictive behaviors, 27(6), 989-993. http://dx.doi.org/10.1016/S0306-4603(02)00300-3

Rogers, E. (2004). A prospective and retrospective look at the diffusion model. Journal of Health Communication, 9.S1, 13-19. http://dx.doi.org/10.1080/10810730490271449

Rok, A., \& Kuhn, S. (2012). Local Sustainability 2012: Taking stock and moving forward - Global review (pp. 87): ICLEI International Council for Local Environmental Initiatives.

Rowe, J. (2000). The local agenda 21 issue commission in bath and North - East Somerset: Review of a community consultation exercise towards sustainability. Local Government Studies, 26(2), 71-92. http://dx.doi.org/10.1080/03003930008433990

Sancassiani, W. (2005). Local agenda 21 in Italy: An effective governance tool for facilitating local communities' participation and promoting capacity building for sustainability. Local Environment: The International Journal of Justice and Sustainability, 10(2), 189-200. http://dx.doi.org/10.1080/1354983052000330770

Schmidt, L., Nave, J., \& Guerra, J. (2005). Autarquias e desenvolvimento sustentável: Agenda 21 Local e novas estratégias ambientais (2. ed.). Porto: Fronteira do Caos.

Schmidt, L., Nave, J., \& Guerra, J. (2006). Who's afraid of Local Agenda 21? Top-down and bottom-up perspectives on local sustainability. International Journal of Environment and Sustainable Development, 5(2). http://dx.doi.org/10.1504/IJESD.2006.009380

Scott, J. (2006). "E" the people: Do US municipal government Web sites support public involvement? Public Administration Review, 66(3), 341-353. http://dx.doi.org/10.1111/j.1540-6210.2006.00593.x

Scott, W. (1995). Institutions and organizations - Foundations for organizational science. London: A Sage Publication Series.

Selman, P. (1998). Local Agenda 21: Substance or Spin? Journal of Environmental Planning and Management, 41(5), 533-553. http://dx.doi.org/10.1080/09640569811443

Selman, P. (2000). A Sideways Look at Local Agenda 21. Journal of Environmental Policy and Planning, 2, 39-53. http://dx.doi.org/10.1080/738552353

Selman, P. (2010). Local authorities' initiatives in support of AGENDA 21—Europe. Retrieved 10 July 2013, from Eolss Publishers, developed under the Auspices of the UNESCO

Seyfang, G., \& Smith, A. (2007). Grassroots innovations for sustainable development: Towards a new research and policy agenda. Environmental Politics, 16(4), 584-603. http://dx.doi.org/10.1080/09644010701419121

Shipan, C., \& Volden, C. (2008). The Mechanisms of Policy Diffusion. American Journal of Political Science, 52(4), 840-857. http://dx.doi.org/10.1111/j.1540-5907.2008.00346.x

Silva, F., \& Gonçalves, V. (2005). Agenda 21 Local. Cadernos Metrópole, 14, 149-174. 
Smardon, R. (2008). A comparison of Local Agenda 21 implementation in North American, European and Indian cities. Management of Environmental Quality: An International Journal, 19(1), 118-137. http://dx.doi.org/10.1108/14777830810840408

Sneddon, C., \& Norgaard, R. (2006). Sustainable development in a post-Brundtland world. Ecological Economics, 57, 253-268. http://dx.doi.org/10.1016/j.ecolecon.2005.04.013

Truffer, B., \& Coenen, L. (2012). Environmental Innovation and Sustainability Transitions in Regional Studies. Regional Studies, 46(1), 1-21. http://dx.doi.org/10.1080/00343404.2012.646164

United Nations Conference on Sustainable Development. (2012). The Future We Want. Rio de Janeiro: United Nations.

Walker, R. (2006). Innovation type and diffusion: An empirical analysis of local government. Public Administration, 84(2), 311-335. http://dx.doi.org/10.1111/j.1467-9299.2006.00004.x

Wolman, H., \& Page, E. (2002). Policy Transfer among Local Governments: An Information-Theory Approach. Governance, 15(4), 577-501. http://dx.doi.org/10.1111/1468-0491.00198

\section{Copyrights}

Copyright for this article is retained by the author(s), with first publication rights granted to the journal.

This is an open-access article distributed under the terms and conditions of the Creative Commons Attribution license (http://creativecommons.org/licenses/by/3.0/). 